\title{
The Implementation of Regional Regulations in the Process of Filling in the Village Civil Service
}

\author{
Siti Zuliyah*) and Triwahyuningsih Triwahyuningsih**) \\ *) Universitas Ahmad Dahlan Yogyakarta, E-mail: sitizuliyah@gmail.com \\ $\left.{ }^{* *}\right)$ Universitas Ahmad Dahlan Yogyakarta, E-mail: ppkn@uad.ac.id
}

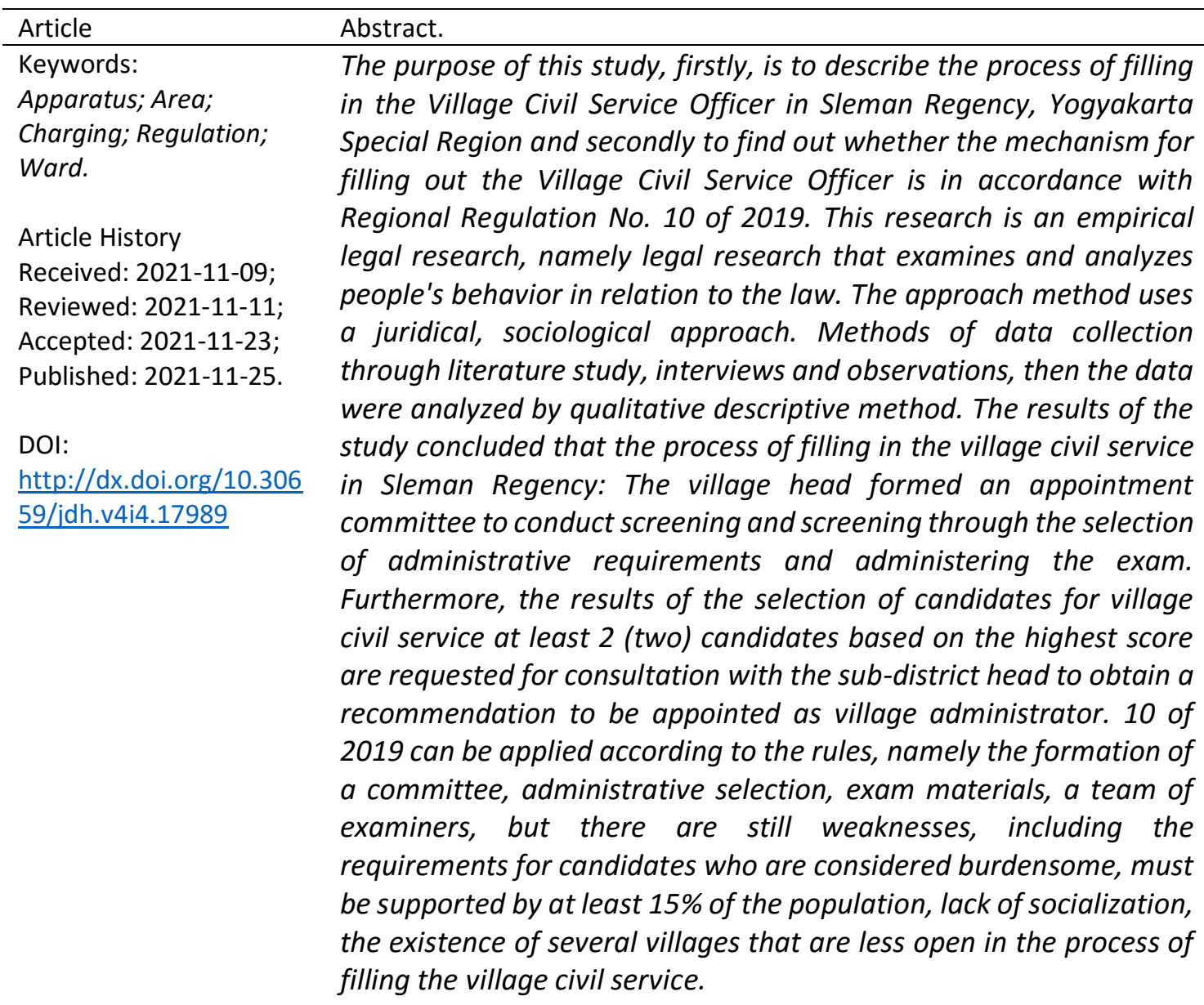

(C)2021; This is an Open Access Research distributed under the term of the Creative Commons Attribution License (https://Creativecommons.org/licences/by/4.0), which permits unrestricted use, distribution, and reproduction in any medium, provided the original works is properly cited

\section{Introduction}

In the current era of regional autonomy, in general regional development is directed so that regions are able to be independent in terms of development financing and have competitiveness with other regions. ${ }^{1}$. However, to find these two things, each region has various obstacles, both regarding internal and external factors. To achieve

\footnotetext{
${ }^{1}$ Nawawi, M. (2018). Pentingnya Kualitas Aparat Pemerintah Desa Dalam Pembangunan Di Desa Bedilan Kecamatan Belitang Kabupaten Oku Timur. Jurnal Aktual STIE Trisna Negara Volume 16 (1) June, p. 2838
} 
the success of regional autonomy, many regions have certain policies. The policies taken are intended as a basis for reference to be able to carry out certain actions, one of which is to make the authority of the village organizational structure. ${ }^{2}$

The rationale in the regulation of village government is diversity, participation, genuine autonomy and community empowerment. Thus, this regulation on autonomy aims to carry out autonomy by providing broad, real and responsible authority ${ }^{3}$. The village as the lowest government organization and is the position closest to the community is the foundation of all government affairs that are above it, the village government must have adequate authority.

In Article 1 of Act No. 13 of 2012 concerning the Privileges of the Special Region of Yogyakarta that the Special Region of Yogyakarta, hereinafter abbreviated as DIY, is one of the provinces in Indonesia that has privileges in the administration of government affairs. These privileges are the privileges of the legal position owned by DIY based on history and original rights according to the 1945 Constitution of the Republic of Indonesia to regulate and administer special powers. Sleman Regency is one of the regencies in the Special Region of Yogyakarta (DIY) in addition to Kulon Progo Regency, Bantul Regency, Gunung Kidul Regency and Jogjakarta City. In the Regulation of the Governor of DIY No. 25 of 2019 it is stated that Village of is part of the area of Kapanewon/Kemantren as an apparatus of Kapanewon/Kemantren.

In Act No. 6 of 2014 concerning Villages, it is stated that the village government consists of the village head assisted by village officials as an element of village administration, thus elements of village apparatus have an important position in the organizational structure of the village government. However, the problem is that not all villages in Indonesia in general and especially in Sleman Regency have a village organizational structure with a complete village apparatus, in the sense that there is a vacancy in the position of village officials which makes the village government less stable. In order to anticipate that there will be no vacancies in village apparatus positions, the village government makes policies regarding village apparatus regulations or village officials, namely in Sleman Regency, DIY through Regional Regulation No. 10 of 2019. This research raises the issue. how is the process of filling the village civil service in Sleman DIY district? Is the process of filling in the village civil service in Sleman district in accordance with regional regulation No. 10 Years 2019 ?

\section{Research Methods}

This research is an empirical legal research, namely legal research that examines and analyzes people's behavior in relation to the law ${ }^{4}$. The approach used is sociological juridical, namely a research conducted on the real situation of society with the aim of knowing the application of law in society. Methods of collecting data through literature

\footnotetext{
2 Thahir, B. (2019). Kebijakan Sosial Dan Otonomi Daerah, Jurnal Kebijakan Pemerintahan, Volume 2, Nomor 2, p. 1-12

3 Namlis, A. (2018). Dinamika Implementasi Penyelenggaraan Pemerintahan Daerah. Jurnal Kajian Pemerintahan Volume IV Nomor 1 March, p. 41

${ }^{4}$ Marzuki, P. M. (2008). Penelitian Hukum. Jakarta: Kencana, p. 87 and Faisal, S. (1990). Penelitian Kualitatif. Malang: Dasar dasar dan Aplikasi YA3.
} 
study, interviews and observations, then the data were analyzed by qualitative descriptive methods.

\section{Results and Discussion}

\subsection{Study on Regency/City Government Institutions and Village Heads in DIY}

The Province of the Special Region of Yogyakarta (DIY) is an area that includes: the City of Yogyakarta, Sleman Regency, Bantul Regency, Kulon Progo Regency, and Gunungkidul Regency. Article 8 paragraph (1) of Act No. 13 of 2012 concerning the Privileges of DIY states that DIY has a special form and structure of government. The specialty is that the regional government in DIY is the successor to the Nagari administration of the Sultanate and Duchy and which is constantly changing in line with the system of central government administration within the framework of the Unitary State of the Republic of Indonesia. ${ }^{5}$

The existence of Regencies/Cities and Village is an inseparable part of the structure and organization of the Sultanate and Duchy. The position of Village as the lowest level of government in the government of the Sultanate / Duchy. Regency/City and Village institutions are aligned so that the vision and mission of DIY development and the implementation of privileged affairs can be realized. This privilege affair is held in the form of assignment to the Regency/City Government and Head of Village. The special affairs of the DIY Regional Government may assign some privileged matters to the Regency/City Government and the Headquarters, thus the Regency/Municipal regional apparatus in addition to carrying out the Government Affairs under their authority also carry out the assignments assigned by the DIY Regional Government. ${ }^{6}$.

The social and cultural aspects view the village as an association of community members who know each other, interact and there are certain similarities between them and their lives depend a lot on the natural surroundings. ${ }^{7}$. Therefore, the village is a community whose life is still simple both organizationally, and still upholds local traditions and customs, lives as it is and the level of education is generally low. ${ }^{8}$ HAW Widjaja, the village is an association of legal communities in which there is a composition of indigenous people based on the rights of origin that are special. The basic argument is that Village Government is diversity, community participation (participation), genuine autonomy, democratization and community empowerment. ${ }^{9}$ Act No. 6 of 2014 concerning Villages, the village is a legal community unit that has clear geographical boundaries to run the government of local residents based on the community, origin

\footnotetext{
${ }^{5}$ Soekanto, S., and Mamuji, S. (2010). Penelitian Hukum Normatif Suatu Tinjauan Singkat. Jakarta: Raja Grafindo Persada, p. 34

${ }^{6}$ General Explanation of Regulation of the Governor of DIY No. 25 of 2019 concerning Institutional Guidelines for Privileges in Regency/City Governments and Headquarters.

${ }^{7}$ Ibid.

8 Antara, J. (2000). Akses Bawah demokrasi, Otonomi dan Pemberdayaan Desa. Yogyakarta: Lapera Pustaka Utama, p. 10

9 Hantoro, N. M. (2013). Perubahan Status Desa Menjadi Keturahan Dalam Sistem Ketatanegaraan". Kajian, Vol. 78 No. 4 . p. 237-252
} 
rights, and or traditional rights that are recognized and respected in the Unitary State of the Republic of Indonesia. ${ }^{10}$

Based on the above understanding, village authority includes: authority in the field of village administration, implementation of village development, village community development, and village community empowerment based on community initiative, origins and village customs. Meanwhile, according to Act No. 6 of 2014 the village is authorized to: (a) based on the right of origin; (b) local village scale; (c) The authority of the government above it; (d) The assigned authority of the government above it from both the province and the regency/city. ${ }^{11}$

\subsubsection{Village government}

The village government is the village head or what is called by another name assisted by village officials as an element of village administration ${ }^{12}$ The duties of the village head are to carry out village development, village community development and village community empowerment, in carrying out their duties, the Village Head has the authority to: (a) Lead the administration of village governance; (b) Appointing and dismissing village officials; (c) Holding the power of managing village finances and assets (d) Establishing village regulations; (e) Establish a village revenue and expenditure budget; (f) Fostering village community life; (g) Fostering peace and order in the village community; (h) Fostering and improving the village economy and integrating it in order to achieve a productive scale economy for the greatest prosperity of the village community; (i) Develop village income sources; (j) Utilizing appropriate technology; (k) Coordinate village development in a participatory manner; (I) Represent the village inside and outside the court or appoint a legal representative to represent it in accordance with the provisions of the legislation; $(\mathrm{m})$ Carry out other authorities in accordance with the provisions of laws and regulations. ${ }^{13}$

According to Act No. 6 of 2014 Article 26 states that in carrying out their duties, the village head has the right to: (a) propose the organizational structure and working procedures of the village government; (b) Proposing drafts and enacting village regulations; (c) Receive regular monthly income, allowances and other legal receipts, as well as health insurance; (d) Obtain legal protection for the policies implemented; (e) To mandate the implementation of other duties and obligations to village officials. ${ }^{14}$ The village head is obliged to carry out the basic mandate of the State and the Constitution; realizing the welfare of the village community; Maintain peace and order in the village community; Obedient and obedient to applicable regulations; Implementing the principles of democracy by paying attention to women's rights; Carry out good village governance (good governance); can cooperate; administrative order and others as regulated by law. ${ }^{15}$ In addition, the village is obliged to report the administration of government at the end of each year and at the end of the term of office to the Regent/Mayor, BPD and to the community they lead.

\footnotetext{
${ }^{10}$ Article 1 of Act No. 6 of 2014 concerning Villages

${ }^{11}$ Article 18 of Act No. 6 of 2014

${ }^{12}$ Article 1 of Act No. 6 of 2014

${ }^{13}$ Article 26 (2) of Act No. 6 of 2014

${ }^{14}$ Article 26 (3) of Act No. 6 of 2014

${ }^{15}$ Article 26(4) of Act No. 6 of 2014
} 


\subsubsection{Village Apparatus (Village Civil Service)}

The village apparatus includes: 1. Village Secretary, 2. Regional Executive, 3. Technical Implementation. The task is to assist the village head in carrying out his duties and authorities. Appointed by the village head after consulting the sub-district head on behalf of the regent/mayor, so that he is fully responsible to the village head. Requirements Village officials are local villagers with at least high school education or the equivalent; a minimum age of 20 years and a maximum of 42 years; registered as a resident of the village and settled for at least one year prior to registration, and other conditions regulated in the Perda ${ }^{16}$.

Village apparatus terminates upon death or at their own request, and is terminated if: a.) is 60 years old, b.) is permanently absent, c.) no longer meets the requirements as village apparatus and, d.) violates the prohibition as village apparatus. ${ }^{17}$ For further provisions regarding village apparatus, it is regulated in a regional/district/city regulation which in this study is in Sleman Regency through Regional Regulation no. 10 of 2019 concerning the Village "Pamong" Procedures for filling out and forming village officials. The regulation serves as a reference for the village government in the process of appointing and dismissing Village Apparatus ("Pamong" Village of).

\subsection{The process of filling in the Village "Pamong" in Sleman Regency}

Referring to "Minister of Home Affairs Regulation No. 83 of 2015 concerning the Appointment and Dismissal of Village Apparatus", the Village Head is given full authority as a village leader in terms of appointing and dismissing the Village "Pamong" in accordance with the law. Although previously you have to consult with the District Head to get approval on the appointment and dismissal of the Village of "Pamong"18. The process for filling in the Village of "Pamong" begins with the Village Head forming a committee with a maximum of 11 (eleven) people consisting of 1 (one) Chairperson, 1 concurrently member, 1 (one) secretary concurrently a member and, members whose elements consist of a. Village apparatus b. BPD c. Village Community Institutions and d. Community Leaders.[19]. Furthermore, the appointment committee conducts screening and screening. The appointment committee conducts screening of prospective candidates by:

"Announcing the implementation of the appointment of village officials in a place that is easy for the public to read; Disseminate vacancies for vacant village apparatus positions including requirements and procedures for screening and screening candidates for village apparatus; and Receive the registration of prospective candidates ${ }^{19}$."

The selection is carried out through a selection of administrative requirements that have been regulated in Article 15 of Regional Regulation No. 10 of 2019. The

\footnotetext{
${ }^{16}$ Article $48-50$ of Act No. 6 of 2014

${ }^{17}$ Article 53 of Act No. 6 of 2014

${ }^{18}$ Article 4 Regulation of the Minister of Home Affairs Number 83 of 2015 concerning the Appointment and Dismissal of Village Apparatus

${ }^{19}$ Article 18 of Regional Regulation Number 10 of 2019 concerning Procedures for Filling and Dismissing Village Apparatus
} 
appointment committee determines prospective candidates who meet the administrative requirements as candidates who are entitled to take the exam. While the screening is done through the implementation of the test. According to Sleman Regional Regulation No. 10 of 2019 concerning Procedures for Filling and Dismissing Village Apparatus in Article 19 paragraph 2, states that the implementation of the exam must cooperate with universities accredited by the lowest institution B and have competence related to exam material. The committee for the appointment of the examination administration as referred to in Article 18 paragraph (1) of Regional Regulation No. 10 of 2019, covering: Written exam Includes: (1) Academic Potential Test; (2) Field proficiency tests include Pancasila, the 1945 Constitution, the government system of the Republic of Indonesia, Indonesian language, knowledge of regional government, knowledge of village administration, general knowledge, knowledge in accordance with local positions and content; b. Skills exams include: (1) computer practice; (2) Practice giving speeches, presenting and leading Meetings; (3) Psychological tests, and interview tests. ${ }^{20}$

"The result of the selection for the Village Civil Service candidate is a combination of test scores plus the value of working experience in village institutions and locality scores. The value of working experience in village institutions is determined by the length of the work period, while the value of locality is given to prospective village officials who come from residents of the "padukuhan" or local village. The village head submits the results of the screening of candidates for village apparatus at least 2 (two) candidates based on the highest score rating and is consulted with the District Head no later than 2 (two) working days after receiving the screening results from the appointment committee. The District Head conducts research and scrutiny on the appointment of village apparatus including: (1) Requirements for candidates for village apparatus (2) Implementation and mechanism for organizing the screening and screening in accordance with statutory regulations; and (3) The highest score rating. If based on research and scrutiny it is fulfilled, the sub-district head provides recommendations for village officials who get the highest score to the village head no later than 7 (seven) working days after receiving the request for consultation from the village head. ${ }^{21}$

If the District Head does not agree, the Village Head repeats the selection of candidates for village officials. There are several reasons for the refusal from the District Head if: (1) The candidate does not comply with what the law requires; (2) The method of conducting the screening and screening is not in accordance with the Law. Written approval from the sub-district head becomes the basis for the village head in determining the candidate to become a village apparatus with the village head's decision ${ }^{22}$.

\footnotetext{
${ }^{20}$ Article 18 paragraph (1) Regional Regulation Number 10 of 2019 concerning Procedures for Filling and Dismissing Village Apparatus

${ }^{21}$ Article 20-28 of Regional Regulation Number 10 of 2019

${ }^{22}$ Article 28 Paragraph (4) and (5) of Regional Regulation Number 10 of 2019
} 


\subsection{Implementation of Regional Regulation No. 10 of 2019 concerning the Process of Filling in the Village Officials in Sleman Regency}

In Article 5 of Regional Regulation No. 10 of 2019 that the village head as the person in charge of filling in the village apparatus forms an appointment committee. The appointment committee consists of a maximum of 11 (eleven) people consisting of elements of the BPD, village officials, village community institutions and community leaders. According to several village heads in Sleman district, that the number of appointment committees in Sleman amounted to 11 (eleven) people was confirmed by the testing team from UAD. ${ }^{23}$

"The campus involvement is expected to get quality human resources, both academically and morally religiously. A complete package as a prospective leader who can be trusted, has good character, likes to work together, protects with an open process. The third party, Admad Dahlan University, with Adan accreditation, has experience, who is trusted to test village officials in several regencies, such as Bantul, Kulon Progo, Klaten and now Sleman Regency. This openness is expected to attract quality village officials and be able to face various challenges in the future. [SHJ interview, September 4, 2021] $]^{24}$

In the selection of administrative requirements, most of the villages in the Sleman area have met the requirements according to Perda no. 10 of 2019. For example, education level, age and so on, but for the requirement to get support of at least $15 \%$ of the population in the local Padukuhan and evidenced by a photocopy of a supporting ID card, according to sources, the regulation is rather burdensome, considering the number of residents in one hamlet is so large and on average each candidate must have the support of approximately 100 (one hundred) supporters is not an easy thing. ${ }^{25}$

"In principle, everything went smoothly, there were no significant problems. The third party (University) in this case Ahmad Dahlan University carried out both written and skill tests after the candidate had met the administrative requirements and passed. The end result is after adding the value of locality, work experience or the value of the service carried out by the local committee in accordance with the regulation mentioned above. The locality value is proven by an ID card if you have lived in the village for at least the past year. With the addition of a value of ten if it is proven and otherwise the value is empty, aka 0 . Meanwhile, the value of dedication is obtained from the experience of the candidate such as being a manager of organizations in the village, for example, the head of the RT, the head of the RW or the management of the Youth Organization/Youth Organization and the like. There are several objections from the candidates for "Pamong" Dukuh, namely, there must be support from local residents of at least 15 percent. Hopefully there is a wiser way to get the best candidate through an accountable procedure." [Interview with $\mathrm{KP}, \mathrm{SHJ}$, September 4, 2021] ${ }^{26}$

\footnotetext{
${ }^{23}$ Interview with WW on September 4, 2021

24 Interview with SHJ on September 4, 2021

25 Interview with PD on September 5, 2021

${ }^{26}$ Interview with KP, SHJ on 5 September 2021
} 
In Article 14 of Regional Regulation No. 10 of 2019, it is stated that the number of prospective candidates as a result of registration is at least 2 (two) or 3 (three) people for each Village of civil service position formation. According to the informant, most of the villages in Sleman Regency which held filling in the village officials for each formation could reach 9 to 10 people, this was like what happened in Sendangsari village and Sendangrejo Minggir village, but there were also places where only 2 (two) participants, such as occurred in Margorejo Village and other villages in the Sleman area. This can happen where the cause is the lack of socialization about the implementation of filling village civil servants as well as other causes, namely the lack of village formation in the implementation of filling village civil servants. ${ }^{27}$. This is in accordance with the results of research conducted by Siti Zuliyah (2017) regarding the Study of Filling Village Civil Service Vacancies in Bantul Regency, concluding that there are several villages that are less open in the implementation of filling village civil service vacancies. ${ }^{28}$

Another study, conducted by Rahmad Hidayat and Septi Nur Wijayanti (2016) about the village apparatus recruitment system in Poncosari village, Bantul Regency concluded that the village apparatus recruitment system carried out by village officials was less democratic so that it had an adverse impact on the life of the village community concerned. From the results of these studies prove that the rules have not functioned optimally. ${ }^{29}$ This is like the results of research conducted by Sri Hartini and Abdul Azis Nassihudin (2015) regarding the policy study of filling in the Village Secretary in Banyumas Regency which concluded that the appointment procedures carried out in filling the position of Village Secretary were not in accordance with applicable regional regulations so that the legal function could not be realized. ${ }^{30}$

Article 19 Regional Regulation No. 10 of 2019 it is stated that the exam consists of, (a) a written test (b) a skills test (c) a psychological test and (d) an interview test. The determination of the type of exam is based on the quality of the desired human resources, such as the written and psychological exams if you want the candidate for the village civil servant to be smart and intelligent, while in the interview test if you want a village civil servant candidate who has dedication and experience in the field of work, while the practical exam is usually requires prospective village officials who are skilled at work. According to the chairman, the testing team from UAD, that some villages in Sleman district want candidates for village officials who are smart, skilled, highly dedicated and also experienced in work. ${ }^{31}$

Article 19 of regional regulation no. 10 of 2019 it is also stated that the implementation of the mandatory exam involves a campus accredited by an institution of at least B and has the ability in exam material, in this case according to several sources that the Sleman Regency usually takes both state universities (UGM, UNY) and private universities (APMD, UAD). , UMY. Furthermore, Article 28 of Regional Regulation No. 10

\footnotetext{
27 Interview with TT, WW September 4, 2021

28 Zuliyah, S. (2017). Studi Tentang Pengisian Lowongan Pamong Desa Di Kabupaten, Bantul: LPPM Universitas Ahmad Dahlan

${ }^{29}$ Hidayat, R., and Wijayanti, S. N. (2020). Mekanisme Seleksi Perangkat Desa Sebagai Salah Satu Alternatif Mewujudkan Good Governance. MEDIA of LAW and SHARIA Volume 2, No. 1, (1-19)

30 Hartini, S., and Nassihudin, A. A. (2015). "Tentang studi kebijakan pengisian Sekretaris Desa di Kabupaten Banyumas"

${ }^{31}$ Interview with SY on September 24, 2021
} 
of 2019 stipulates that the candidate's test scores are based on the highest score and approval is requested from the sub-district head no later than 2 (two) working days after receiving the screening results from the appointment committee candidate for village civil servants, and if it has been fulfilled,

In principle, the selection of village officials is one way to realize good village governance in order to realize the achievement of the ideals of an independent, democratic and prosperous village. ${ }^{32}$ However, the means and objectives must be good and correct, following the applicable regulations with the main objective of determining village progress or improving the welfare of the village community. Ideally, improvements to village governance will become the focus of the Indonesian nation's future agenda, especially in Sleman Regency, Yogyakarta Special Region.

\section{Conclusion}

The process of filling in the village civil service in Sleman Regency begins with the village head forming an appointment committee to conduct screening and screening of candidates for village civil servants through the selection of administrative requirements and through the administration of examinations for administering exams that must collaborate with an accredited campus with a minimum of $B$ and competent institutions related to the exam material, then the results of the selection of candidates kelurahan shall have at least 2 (two) candidates based on the highest score, who are then requested for consultation with the District Head to obtain a recommendation to be appointed as "Pamong". Implementation of Regional Regulation No. 10 of 2019, in principle, it can be applied according to the rules such as: the formation of an appointment committee, selection of administrative requirements, exam materials, selection of exams, testing teams and so on, but there are still some weaknesses, including: the support requirement of $15 \%$ of citizens who are considered burdensome, lack of socialization Regarding the process of filling the village civil service, the lack of transparency in the process of filling the village civil service is also an obstacle in the implementation of filling the village civil servant in Sleman Regency.

\section{References}

\section{Journals:}

[1] Namlis, A. (2018). Dinamika Implementasi Penyelenggaraan Pemerintahan Daerah. Jurnal Kajian Pemerintahan Volume IV No. 1.

[2] Thahir, B. (2019). Kebijakan Sosial Dan Otonomi Daerah. Jurnal Kebijakan Pemerintahan, Volume 2, No. 2.

[3] Suharto. D. G. (2012). Penyelenggaraan Pemerintahan Desa Dalam Perspektif Desentralisasi Administratif Dan Desentralisasi Politik, Jurnal Bina Praja Volume 4 No. 3

\footnotetext{
32 Suharto, D. G. (2012). Penyelenggaraan Pemerintahan Desa Dalam Perspektif Desentralisasi Administratif Dan Desentralisasi Politik. Jurnal Bina Praja Volume 4 No. 3. p. 153 - 160
} 
[4] Nawawi, M. (2018). Pentingnya Kualitas Aparat Pemerintah Desa Dalam Pembangunan Di Desa Bedilan Kecamatan Belitang Kabupaten Oku Timur. Jurnal Aktual STIE Trisna Negara Volume 16 (1)

[5] Hantoro. N. M. (2013). Perubahan Status Desa Menjadi Keturahan Dalam Sistem Ketatanegaraan. Kajian, Vol. 78 No. 4

[6] Hidayat, R., and Wijayanti, S. N. (2020). Mekanisme Seleksi Perangkat Desa Sebagai Salah Satu Alternatif Mewujudkan Good Governance. MEDIA of LAW and SHARIA Volume 2, No. 1.

\section{Books:}

[1] Antara, J. (2000). Akses Bawah demokrasi, Otonomi dan Pemberdayaan desa. Yogyakarta: Lapera Pustaka Utama

[2] Marzuki, P. M. (2008). Penelitian Hukum. Jakarta: Kencana

[3] Faisal, S. (1990). Penelitian Kualitatif. Malang: Dasar dasar dan Aplikasi YA3.

[4] Zuliyah, S. (2017). Studi Tentang Pengisian Lowongan "Pamong" Desa Di Kabupaten, Bantul: LPPM Universitas Ahmad Dahlan

[5] Soekanto, S., and Mamuji, S. (2010). Penelitian Hukum Normatif Suatu Tinjauan Singkat. Jakarta: Raja Grafindo Persada

[6] Hartini, S and Nassihudin, A. A. (2015). "Tentang studi kebijakan pengisian Sekretaris Desa di Kabupaten Banyumas"

\section{Regulations:}

[1] Article 1 of Act No. 6 of 2014 concerning Villages

[2] Article 18 of Regional Regulation Number 10 of 2019 concerning Procedures for Filling and Dismissing Village Apparatus

[3] Article 4 Regulation of the Minister of Home Affairs Number 83 of 2015 concerning the Appointment and Dismissal of Village Apparatus

\section{Interviews:}

[1] Interview with WW on September 4, 2021

[2] Interview with SHJ on September 4, 2021

[3] Interview with TT, WW September 4, 2021

[4] Interview with PD on September 5, 2021

[5] Interview with KP, SHJ on 5 September 2021

[6] Interview with SY on September 24, 2021 